\title{
ADDITIONAL NOTE ON INHERITANCE OF FE-DEFICIENCY CHLOROSIS IN CHICKPEA (Cicer arietinum $\mathbf{L}$.)
}

\author{
Huseyin CANCI ${ }^{1, *}$, Nisa Ertoy INCI ${ }^{2}$,Fatma Oncu CEYLAN ${ }^{1}$, Tolga YILDIRIM ${ }^{3}$ \\ ${ }^{1}$ Akdeniz University, Faculty of Agriculture, Department of Field Crops, Antalya, TURKEY \\ ${ }^{2}$ Akdeniz University, Kumluca Vocational School, Horticultural Program, Kumluca- Antalya, TURKEY \\ ${ }^{3}$ Akdeniz University, Faculty of Science, Department of Biology, Antalya, TURKEY \\ Corresponding author: huseyincanci@akdeniz.edu.tr
}

Received: 17.04 .2015

\begin{abstract}
When susceptible cultivars are grown in calcareous soils with high $\mathbf{p H}$, significant yield loss due to iron (Fe) deficiency chlorosis is brought about in chickpea (Cicer arietinum $\mathbf{L}$.). One of the most efficient ways for solve this problem is improved of Fe-deficiency chlorosis via conventional breeding methods. In the study, genotypes ICC 4851 and ICC 4858, which are resistant to Fe-deficiency chlorosis, were crossed with genotype ICC 6119, which is susceptible to Fe-deficiency chlorosis, and studied genetics of Fe-deficiency chlorosis in $F_{1}$ and $F_{2}$ segregating generations. Fe-deficiency chlorosis was governed by a major recessive gene and affected by environment factors like high temperature. A negative selection seems to be an effective approach after segregation in $F_{2}$ or later generations.
\end{abstract}

Key words: Chickpea; chlorosis; genetics; iron deficiency; resistance

\section{INTRODUCTION}

The cultivated chickpea (Cicer arietinum L.) is the first rank among cool season food legumes on the basis of harvested area with 12.3 million ha, and it is produced 11.6 million ton. Its globally average seed yield has been increased $318 \mathrm{~kg}$ per ha from $649 \mathrm{~kg}$ (in 1961) to $967 \mathrm{~kg}$ in 2013 (FAOSTAT 2013). However, its seed yield is still too low when compared to its potential seed yield because it is mainly grown in rainfed conditions. In some gates of these areas, it faces some nutrient deficiencies resulting in seed yield losses. One of the most important problems is iron $(\mathrm{Fe})$ deficiency when the susceptible cultivars are grown in the problematic conditions such as in calcareous soil (Gowda and Smithson, 1980; Singh et al., 1986; Ali et al., 1988; Ali et al., 2000; Ohwaki and Sugahara, 1993; Zaiter and Ghalayini, 1994). Seed yield in the cultivated chickpea can reduce by $50 \%$ in Lebanon, Syria and India due to Fe-deficiency (Sakal et al., 1987; Ali et al., 2002). Although Fe-deficiency chlorosis in chickpea can be overcome with application of $10-20 \mathrm{~kg} \mathrm{Fe}$ granular fertilizers per ha (Srinivasarao et al., 2003), high $\mathrm{pH}$ in the calcareous soil may be limited the benefits provided by the application (Ahlawat et al., 2007). The alternative approaches to overcome Fe-deficiency chlorosis is a foliar spray of $250 \mathrm{~L}$ per ha of $1 \% \mathrm{FeSO}_{4}$ (Ahlawat et al., 2007). Both of the applications can mostly be uneconomical and inconvenient since they need additional labor, time and inputs. Thus, one of the most economical and permanent approaches is grown suitable cultivars, which can efficiently obtain $\mathrm{Fe}$ from calcareous soil with high $\mathrm{pH}$ (Coyne et al., 1982; Fehr, 1984; Fairbanks, 2000). Selection of Fe-efficient chickpea genotypes depends on knowledge about its inheritance and genetics is of critical importance. In chickpea, genetics and inheritance of $\mathrm{Fe}$ deficiency chlorosis were studied by Ali et al. (1988), Gowda and Smithson (1980), Halila (1983) and Saxena et al. (1990) but environmental factors have been ignored in these studies made on Fe-deficiency chlorosis. In the present study, it was evaluated inheritance of $\mathrm{Fe}$ deficiency chlorosis in chickpea considering environmental factors viz. temperature.

\section{MATERIALS AND METHODS}

\section{Crosses}

ICC 6119 (), Fe-deficiency chlorosis susceptible genotype (Toker et al., 2010), was crossed with ICC 4951 and ICC $4958(\delta)$, Fe-efficient genotype and resistant to drought (Saxena et al., 1993; Canci and Toker, 2009) at Antalya location (approximately $30^{\circ} 44^{\prime}$ E, $36^{\circ} 52^{\prime}$ N, 51 $\mathrm{m}$ from sea level) under field conditions. Sowing of the materials was done by hand in autumn (November and December) and harvest was done by hand in beginning of the summer. 
Agronomic practices

$F_{1}$ and $F_{2}$ plants were sown and grown at Antalya location in 2005-2006 and 2006-2007 growing seasons under rainfed conditions. Row and plant spacing were adjusted as $45 \mathrm{~cm}$ and $5 \mathrm{~cm}$, respectively. Prior to sowing, fertilization was applied with $\mathrm{N}, \mathrm{P}$ and $\mathrm{K}$ at rate of $20 \mathrm{~kg}$ per ha. Weed control was made by hand. Additional irrigation was not applied.
Screening for Fe-deficiency chlorosis

Materials were screened for Fe-deficiency chlorosis using some modifications of (Table 1) a visual 1-9 scale (Saxena et al., 1990) before flowering stage because Fedeficiency chlorosis in ICC 6119 was transient.

Table 1. A visual 1- 9 scale and reaction category of plants.

\begin{tabular}{lll}
\hline Scale & Reaction category & Visual reaction of plants \\
\hline 1 & Very highly resistant & Plants free from any Fe-deficiency symptoms \\
2 & Highly resistant & $1 \%$ leaflets yellow \\
3 & Resistant & $2-5 \%$ leaflets yellow \\
4 & Moderately resistant & $6-10 \%$ leaflets yellow \\
5 & Intermediate & $11-50 \%$ leaflets and some plants yellow \\
6 & Moderately susceptible & $51-75 \%$ leaflets and about 25\% plants show yellowing \\
7 & Susceptible & $76-80 \%$ leaflets and about 26-50\% plants show yellowing \\
8 & Highly susceptible & $81-99 \%$ leaflets and about 51-75\% plants show yellowing \\
9 & Very highly susceptible & All plants show yellowing color and stopped \\
\hline
\end{tabular}

\section{Characteristics of experimental soil}

Soil sample was taken once before sowing in the first year. Therefore, results of soil analyses were given for one year in Table 2. Soil was high calcareous and moderately alkaline. Available Fe concentration was very low with high $\mathrm{pH}$ in experimental soil.

Table 2. Soil analyses results.

\begin{tabular}{lcc}
\hline Soil Parameters & Results & Interpretation \\
\hline $\mathrm{pH}$ & 7.96 & Moderately alkaline \\
$\mathrm{E} . \mathrm{C}(\mathrm{mS} / \mathrm{cm})$ & 0.93 & No salinity effects \\
$\mathrm{CaCO}_{3}(\%)$ & 26.5 & High calcareous \\
$\mathrm{Sandy}(\%)$ & 45.08 & - \\
$\mathrm{Clay}(\%)$ & 31.28 & - \\
$\mathrm{Silt}(\%)$ & 23.64 & Candy clay loam \\
Texture & & Low \\
Organic matter $(\%)$ & 1.87 & Medium \\
Total N $(\%)$ & 0.106 & Medium \\
Available P (ppm) & 9.37 & Optimum \\
Exchangeable K (meq / 100 g) & 0.61 & Low \\
Exchangeable Na (meq / 100 g) & 0.15 & Optimum \\
Exchangeable Ca (meq / 100 g) & 37.71 & Optimum \\
Exchangeable Mg (meq / 100 g) & 7.12 & Very low \\
Available Fe (ppm) & 3.56 & Low \\
Available $\mathrm{Zn}(\mathrm{ppm})$ & 0.746 & Optimum \\
Available $\mathrm{Mn}(\mathrm{ppm})$ & 23.156 & High \\
Available Cu (ppm) & 1.368 & \\
\hline
\end{tabular}

\section{Records for climatic conditions}

Data for weather condition at Antalya location were presented in Table 3. Maximum temperatures reached up to $43.5^{\circ} \mathrm{C}$ during the growing period.

\section{Statistical analyses}

Chi-squares $(\chi 2)$ test was performed in $\mathrm{F}_{2}$ plants with the following formula: $\chi 2=\Sigma(\mathrm{O}-\mathrm{E})^{2} / \mathrm{E}$, where $\mathrm{E}$ and $\mathrm{O}$ are expected and observed values, respectively (Steel and Torrie, 1980).

\section{RESULTS AND DISCUSSION}

\section{Records for Fe-deficiency chlorosis}

The soil was considered an ideal chose to differentiate of Fe-deficiency and Fe-efficiency in chickpea since Fe content of the soil was found to be low with high $\mathrm{pH}$ (Table 1).

As seen in Table 4, six hybrids were obtained from the cross between ICC 6119 and ICC 4951, while the cross between ICC 6119 and ICC 4958 produced 11 hybrids. 
All $F_{1}$ plants were found as Fe-efficient, while $F_{2}$ plants were segregated in point of $\mathrm{Fe}$-deficiency chlorosis. In $\mathrm{F}_{2}$ observation, 88 plants were recorded as resistant, while 30 plants were recorded as susceptible in cross ICC $6119 \mathrm{x}$
ICC 4958. In the cross ICC 6119 x ICC 4958, 108 plants were found as resistant, while 38 plants were found as susceptible.

Table 3. Weather conditions during 2005-2006 and 2006-2007 growing seasons.

\begin{tabular}{|c|c|c|c|c|c|c|c|c|c|c|}
\hline \multirow{3}{*}{ Months } & \multicolumn{8}{|c|}{ Temperature $\left({ }^{\circ} \mathrm{C}\right)$} & \multirow{2}{*}{\multicolumn{2}{|c|}{ Rainfall (mm) }} \\
\hline & \multicolumn{2}{|c|}{$\begin{array}{c}\text { Average } \\
\text { maximum }\end{array}$} & \multicolumn{2}{|c|}{$\begin{array}{l}\text { Average } \\
\text { minimum }\end{array}$} & \multicolumn{2}{|c|}{$\begin{array}{c}\text { Extreme } \\
\text { maximum }\end{array}$} & \multicolumn{2}{|c|}{$\begin{array}{c}\text { Extreme } \\
\text { minimum }\end{array}$} & & \\
\hline & $\begin{array}{l}2005- \\
2006\end{array}$ & $\begin{array}{l}2006- \\
2007\end{array}$ & $\begin{array}{l}2005- \\
2006\end{array}$ & $\begin{array}{l}2006- \\
2007\end{array}$ & $\begin{array}{l}2005- \\
2006\end{array}$ & $\begin{array}{l}2006- \\
2007\end{array}$ & $\begin{array}{l}2005- \\
2006\end{array}$ & $\begin{array}{l}2006- \\
2007\end{array}$ & $\begin{array}{l}2005- \\
2006\end{array}$ & $\begin{array}{l}2006- \\
2007\end{array}$ \\
\hline October & 25.7 & 25.9 & 14.5 & 15.5 & 31.4 & 33.4 & 9.0 & 12.2 & 17.2 & 494.7 \\
\hline November & 19.9 & 20.2 & 9.7 & 8.7 & 24.4 & 26.0 & 4.8 & 3.8 & 142.2 & 126.4 \\
\hline December & 17.4 & 17.6 & 7.8 & 8.3 & 25.4 & 21.8 & 2.6 & 1.8 & 129.6 & 66.4 \\
\hline January & 14.2 & 16.2 & 5.4 & 8.3 & 18.4 & 21.1 & 1.0 & 4.3 & 319.0 & 136.8 \\
\hline February & 15.9 & 16.0 & 6.9 & 9.0 & 21.4 & 20.7 & 0.2 & 2.4 & 84.5 & 182.6 \\
\hline March & 18.2 & 18.7 & 9.1 & 11.1 & 21.7 & 22.3 & 4.1 & 8.4 & 78.2 & 10.2 \\
\hline April & 22.4 & 22.2 & 12.6 & 13.8 & 29.4 & 27.3 & 9.2 & 10.5 & 87.3 & 1.6 \\
\hline May & 26.9 & 25.6 & 15.4 & 18.9 & 40.2 & 35.0 & 10.8 & 14.0 & 12.3 & 5.2 \\
\hline June & 31.5 & 31.7 & 20.4 & 23.8 & 38.2 & 43.5 & 16.0 & 17.8 & 21.9 & 1.4 \\
\hline
\end{tabular}

Table 4. Segregation for Fe-deficiency chlorosis in $\mathrm{F}_{2}$ progeny.

\begin{tabular}{|c|c|c|c|c|c|}
\hline \multicolumn{2}{|c|}{ Crosses } & \multirow{2}{*}{$\begin{array}{c}\mathbf{F}_{1} \\
\text { No. of R:S } \\
\text { Plants }\end{array}$} & \multicolumn{3}{|c|}{$\mathbf{F}_{2}$} \\
\hline $\begin{array}{l}\text { Susceptible } \\
\text { (S) }\end{array}$ & $\begin{array}{l}\text { Resistant } \\
\text { (R) }\end{array}$ & & $\begin{array}{l}\text { No. of R:S } \\
\text { Plants }\end{array}$ & Expected & $\chi^{2}$ \\
\hline ICC 6119 (q) & ICC $4951\left({ }^{\Uparrow}\right)$ & 6 Resistant & $\begin{array}{l}88 \text { Resistant: } \\
30 \text { Susceptible }\end{array}$ & $3: 1$ & 0.01 \\
\hline ICC 6119 (q) & ICC $4958(\overbrace{}^{\Uparrow})$ & 11 Resistant & $\begin{array}{l}108 \text { Resistant: } \\
38 \text { Susceptible }\end{array}$ & $3: 1$ & 0.08 \\
\hline
\end{tabular}

Ratio for Fe-efficiency and Fe-deficiency in $\mathrm{F}_{2}$ plants was found as fixed well for 3:1 segregating ratio (Table 4). These finding shows that Fe-deficiency chlorosis is governed by a major recessive gene with minor genes since Fe-deficiency were affected by environmental effects such as high temperature. Fe-deficiency chlorosis disappeared after air temperatures rose to $40^{\circ} \mathrm{C}$ in May (Table 2) indicating that it is affected by temperature. Prior to the present study, monogenic inheritance for Fedeficiency chlorosis has been reported in chickpea (Gowda and Rao,1986; Saxena et al., 1990; Toker et al., 2010). $F_{2}$ plants show continuous distribution for $\mathrm{Fe}-$ deficiency and Fe-efficiency (Fig. 1). Distribution of $F_{2}$ plants (Fig 1) indicated that there were small genes effects on Fe-deficiency chlorosis. Gumber et al. (1997) reported that Fe-deficiency chlorosis was controlled by two homozygous recessive genes, and the irrigation also increases Fe-deficiency chlorosis in chickpea. Bejiga et al. (1996) found that Fe-deficiency chlorosis was more outshined problem in autumn-sown chickpeas when compared to traditional spring-sown crops. In lentil (Lens culinaris Medik.), Erskine et al. (1993) pointed out that Fe-deficiency chlorosis was transient since Fe-deficiency symptoms disappeared under day length and high temperature conditions. In faba bean (Vicia faba L.) and pea (Pisum sativum L.), environmental effects on $\mathrm{Fe}$ deficiency chlorosis was reported by Kosagarten et al.
(1988) and Kabir et al. (2013). In common bean (Phaseolus vulgaris L.), Fe-deficiency chlorosis is primarily governed by two complementary dominant genes (Zaiter et al., 1987).

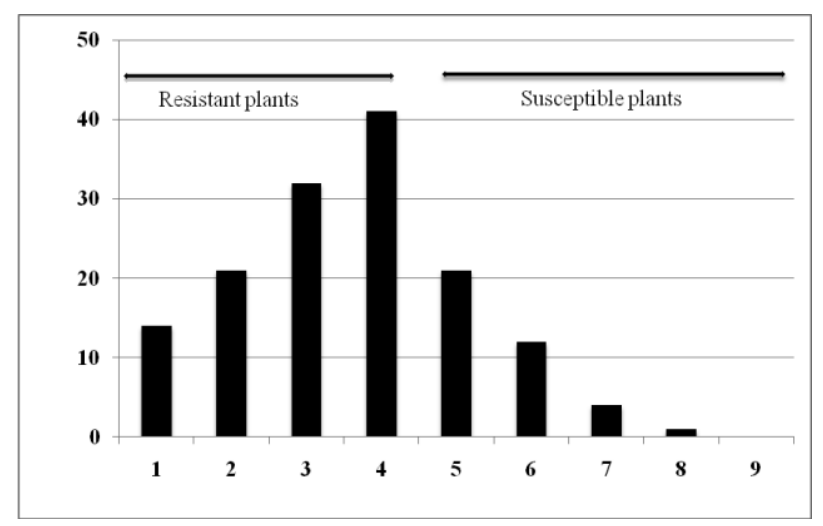

Figure 1. Visual scale (1- 9) for resistance to Fe-deficiency chlorosis in $\mathrm{F}_{2}$.

In chickpea, the gene symbols ' $f e$ ' for susceptibility and ' $F e$ ' for Fe-efficiency and Fe-deficiency chlorosiswere used by Gowda and Rao (1986) and Toker et al. (2010). In the present study, it was suggested that the gene symbols ' $\mathrm{Fe}$ ' and ' $f e$ ' could be used for resistance and susceptipllity, respectively. In irrigated chickpea, YI 
and $Y 2$ and $y 1$ and $y 2$ were used for Fe-efficiency and Fedeficiency chlorosis, respectively (Gumber et al., 1997).

To breed Fe-efficient chickpea, Saxena et al. (1990) suggested that plants susceptible to Fe-deficiency chlorosis should be removed in $\mathrm{F}_{2}$ and later generations. Similarly, Toker et al. (2010) pyramided both of genes for resistance to Fe-deficiency and leaf miner (Liriomyza cicerina Rond.) after $\mathrm{M}_{2}$. In conclusion, Fe-deficiency chlorosis was governed by a single recessive gene with minor genes affected by high temperature. Also, negative selection will be effective in $\mathrm{F}_{2}$ and later generations.

\section{ACKNOWLEDGEMENTS}

This study was supported by Akdeniz University Scientific Research Projects Coordination Unit. We would like to thank International Crops Research Institute for the Semi-Arid Tropics (ICRISAT) for kindly supplying materials and two anonymous reviewers for their constructive comments to improve our manuscript.

\section{LITERATURE CITED}

Ahlawat, I.P.S., B. Gangaiah and M.A. Zahid. 2007. Nutrient management in chickpea. In: S.S. Yadav, B. Redden, W Chen and D.B. Sharma (Eds.) Chickpea breeding and management, CAB International, Wallingford, pp: 213-232.

Ali, A., C. Yousef and M. Tufall. 1988. Screening of desi and kabuli chickpea types for iron-deficiency chlorosis. International Chickpea Newsletter 18: 5-6.

Ali, M., R. Daham, J.P. Mishra and N.P. Saxena. 2000. Towards the more efficient use of water and nutrients in food legume cropping. In: R. Knight (Ed.) Linking Research and Marketing Opportunities for Pulses in the 21st Century, Dordrecht, the Netherlands, Kluwer Academic, pp: 355-368.

Ali, M.Y., L. Krishnamurthy, N.P. Saxena, O.P. Rupela, J. Kumar and C. Johansen. 2002. Scope for genetic manipulation of mineral acquisition in chickpea. Plant and Soil 245: 123-134.

Bejiga, G., K.B. Singh and M.C. Saxena. 1996. Evaluation of world collection of kabuli chickpea for resistance to irondeficiency chlorosis. Genetic Resource and Crop Evolution 43: 257-259.

Canci, H. and C. Toker. 2009. Evaluation of Yield Criteria for Drought and Heat Resistance in Chickpea (Cicer arietinum L.). J. Agronomy and Crop Science 195: 47-54.

Coyne, D.P., S.S. Korban, D. Knudsen and R.B. Clark. 1982 Inheritance of iron-deficiency in crosses of dry beans (Phaseolus vulgaris L.). Journal of Plant Nutrition 5: 575585.

Erskine, W., N.P. Saxena and M.C. Saxena. 1993. Iron deficiency in lentil: Yield loss and geographic distribution in a germplasm collection. Plant and Soil 151: 249-254.

Fairbanks, D.J. 2000. Development of genetic resistance to irondeficiency chlorosis in soybean. Journal of Plant Nutrition 23: 1903-1913.

FAOSTAT 2013. Available at http://www.faostat.fao.org/. (Accessed April 03, 2015)
Fehr, W.R. 1984. Current practices for correcting iron-deficiency in plants with emphasis on genetics. Journal of Plant Nutrition 7: 347-354.

Gowda, C.L.L. and J.B. Smithson. 1980. Iron chlorosis in chickpea. International Chickpea Newsletter 3: 10.

Gowda, C.L.L. and B. Rao. 1986. Inheritance of susceptibility to iron chlorosis in chickpea. International Chickpea Newsletter 15: 7-8.

Gumber, R.K., S. Singh, S. Gill and P.K. Rathore. 1997. Genetics of irrigated- induced iron chlorosis in chickpea. International Chickpea Pigeonpea Newsletter 4: 10-11.

Halila, H. 1983. Screening chickpea for iron chlorosis. International Chickpea Newsletter 9: 14-15.

Kabir, A.H., N.G. Paltridge, U. Roessner and J.C.R. Stangoulis. 2013. Mechanisms associated with Fe-deficiency tolerance and signaling in shoots of Pisum sativum. Physiologia Plantarum 147: 381-395.

Kosegarten, H., U. Schwed, G. Wilson and K. Mengel. 1998. Comparative investigation on the susceptibility of faba bean (Vicia faba L.) and sunflower (Helianthus annuus L.) to iron chlorosis. Journal of Plant Nutrition 21: 1511-1528.

Ohwaki, Y. and K. Sugahara. 1993. Genotypic differences in responses to iron-deficiency between sensitive and resistant cultivars of chickpea (Cicer arietinum L.). Plant and Soil 156: 473-476.

Sakal R., R.B. Sinha and A.P. Singha. 1987. Response of chickpea to iron application in a calcareous soil. International Chickpea Newsletter 16: 14-15.

Saxena M.C., R.S. Malhotra and K.B. Singh. 1990. Irondeficiency in chickpea in the Mediterranean region and its control through resistant genotypes and nutrient application. In: N. El-Bassam, M. Dambroth and B.C. Loughman (Eds.) Genetic Aspects of Mineral Nutrition, Dordrecht, the Netherlands, Kluwer Academic Publishers, pp: 381-384.

Saxena, N.P., L. Krishnamurthy and C. Johansen. 1993. Registration of drought-resistant chickpea germplasm. Crop Science 33: 1424

Singh, R.A., N.P. Sinha, B.P. Singh and S.G. Sharma. 1986. Reaction of chickpea genotypes to iron-deficiency in a calcareous soil. Journal of Plant Nutrition 9: 417-422.

Srinivasarao, C.H., A.N. Ganeshamurthy and M. Ali. 2003. Nutritional Constraints in Pulse Production. Indian Institute of Pulses Research, Kanpur.

Steel, R.G.D. and J.H. Torrie. 1980. Principles and Procedures of Statistics: A Biometrical Approach. 2. ed. New York: McGraw- Hill Publ. Company.

Toker C., T. Yildirim, H. Canci, N.E. Inci and F.O. Ceylan. 2010. Inheritance of resistance to iron deficiency chlorosis in chickpea (Cicer arietinum L.). Journal of Plant Nutrition 33:1366-1373.

Zaiter, H.Z., D.P. Coyne and R.B. Clark. 1987. Genetic-variation and inheritance of resistance of leaf iron-deficiency chlorosis in dry beans. Journal of the American Society for Horticultural Science 112: 1019-1022.

Zaiter, H.Z. and A. Ghalayini. 1994. Iron deficiency in lentils in the Mediterranean region and its control through resistant genotypes and nutrient application. Journal of Plant Nutrition 17: $945-952$. 